\title{
A ESCRITA CRIATIVA: ORIGINALIDADE, BLOQUEIOS E FASES
}

\section{MARCHIONI, Rubens. Escrita criativa: da ideia ao texto.} São Paulo: Contexto, 2018

\section{João de Sá Araújo Trapiá Filho ${ }^{1}$ Geam Karlo-Gomes ${ }^{2}$}

Com o objetivo de "revelar o segredo da arte fascinante de criar e escrever" (MARCHIONI, 2018, p.11), a obra Escrita criativa: da ideia ao texto (2019), de Rubens Marchioni, lançando mão de diversas áreas - propaganda, jornalismo, literatura, filosofia -, apresenta técnicas de escrita destinadas a "quem já é escritor ou quem quer começar a escrever - seja ficção ou não" (Ibid.).

O próprio modo de construção do texto revela a realidade criativa: uma envolvente "costura" de ideias, fontes, citações, orientações, sugestões e recomendações do autor sobre a arte de criar e escrever. Em outras palavras, ele recorre a vozes e ideias de escritores, pensadores - grandes nomes que foram criativos, fossem literatos ou não, como Carlos Drummond de Andrade, escritor brasileiro, e Tupac Amaru Jose Gabriel Condorcanqui, líder indígena do Peru.

Uma obra tão abundante, expressiva e multifacetada só poderia ter sido escrita por quem detém uma experiência de semelhante abrangência. Rubens Marchioni, escritor, jornalista, publicitário e palestrante, buscou nas suas profissões a pluralidade dos exemplos que são apresentados para corroborar ou até mesmo refutar a sua ideia a

\footnotetext{
${ }^{1}$ Mestrando pelo Programa de Pós-Graduação em Educação, Cultura e Territórios Semiáridos (PPGESA), da Universidade do Estado da Bahia (UNEB). Integrante do ITESI - Grupo de Pesquisa em Estudos Sobre o Imaginário, Linguagens e Culturas (UPE/CNPq). E-mail: jsatf@ hotmail.com.

${ }^{2}$ Doutor em Literatura e Interculturalidade. Professor Adjunto da Universidade de Pernambuco (UPE) e Professor dos Programas de Pós-Graduação Formação de Professores e Práticas Interdisciplinares PPGFPPI/UPE e de Pós-Graduação em Educação, Cultura e Territórios Semiáridos PPGESA/UNEB. Líder do Grupo de Pesquisa Itinerários Interdisciplinares em Estudos Sobre o Imaginário (UPE/CNPq). ORCID: https://orcid.org/0000-0001-9569-1497.E-mail: gkgomes@uneb.br 
respeito da escrita criativa e dos seus elementos, apresentando a face democrática do livro.

Nesta resenha, buscou-se analisar a primeira parte da obra, intitulada Criatividade: pensar de maneira diferente para encontrar caminhos inesperados, que se divide em três grandes tópicos: 1 Para começo de conversa; 2 Originalidade. E tudo se faz novo; e 3 Etapas e bloqueios. Caminhos e descaminhos.

No primeiro tópico, Para começo de conversa, percebe-se o caráter dialógico, reflexivo e didático do livro, que orienta o escritor veterano, ou o novo escritor, a preocupar-se com os vários fatores que favorecem a criação da escrita, inclusive com o próprio corpo, que precisa estar com acessórios "que o deixem a vontade" (MARCHIONI, 2018, p.18). Por conseguinte, outros pontos relevantes são abordados, dentre eles, a meta, o objetivo, a disciplina, o público-alvo.

Em Originalidade - E tudo se faz novo, ressalta-se a questão da originalidade e a importância do repertório na formação do novo. Neste ponto, a criatividade e o oposto ao clichê: o desgaste do uso das expressões. Porém, a lista que Marchioni (2018) sugere que seja evitada soa um tanto radical, visto que, dependendo do contexto de uso e da intenção comunicativa, tais expressões podem ser utilizadas.

Em Etapas e Bloqueios - Caminhos e descaminhos, Marchioni (2018) trata dos muitos "monstros" responsáveis por mutilarem a produção de ideias, como a rotina e a acomodação, o medo do ridículo, o imediatismo entre outros. Para que estes "monstros" sejam aniquilados, o autor elenca sete fases a serem seguidas.

A primeira delas, Identificação - Saber a pergunta e estar mais perto da resposta, pondera a importância de se ter uma pergunta/objetivo em mente para o processo de escrita. Tendo consciência da dificuldade que existe em tal empreitada, Marchioni (2018), de forma lúdica e descontraída, sugere que o escritor pense "fora da caixa" e o aconselha a perguntar as coisas como elas gostariam de ser.

A segunda, Preparação - Conhecimento e poder, está atrelada ao objetivo e a pergunta desenvolvidos na primeira, e pode acontecer de forma direta ou indireta. Naquela, a busca por "informações” acontece dentro da área em que o texto produzido versará; nesta, refere-se a busca de "formações" fora da área tratada. Segundo o autor, nesta etapa, além da leitura, e preciso digerir as palavras. 
Na terceira, Incubação - Dê um tempo para as suas futuras ideias, o autor (2018) discute o valor do momento em que o inconsciente assume o controle. Este estágio se mostra importante já que o inconsciente é o "fogo brando" das informações. Pode-se associar essa fase à afirmação de Alencar (1986), que, ao defender a importância da sinética, aborda a relevância do inconsciente para o processo criativo.

$\mathrm{Na}$ quarta fase, Aquecimento - Abra as portas para a nova ideia, evidencia-se uma técnica antiga e muito aclamada quando o assunto e criatividade: a Brainstorming (tempestade de ideias), que consiste em emissão de opiniões, sem valoração inicial, que, futuramente, podem ser analisadas para testar-se a consistência. Neste momento, o “juiz" é suspenso e pontos fundamentais acerca da escrita são abordados, revelando consciência do labor que é escrever.

A quinta fase, Eureca! Iluminação - Surpreenda-se, Marchioni (2018) inicia com uma pergunta norteadora: “Como nasce uma ideia?", a qual é respondida a partir do que seria um diálogo com Bandeira (1984), o poeta o qual afirma que a poesia está em tudo. Por isso, para o autor (2018), a ideia pode vir "acordando no meio da noite", “ou "durante uma reunião chata" (MARCHIONI, 2018, p.66). Daí a necessidade de estar atento(a) e sempre com algo em que possa escrever.

A sexta fase e Elaboração - A ideia toma corpo constitui a sexta fase de aniquilação dos “monstros”. Para Marchioni (2018), ela consiste no ato propriamente da escrita, que requer do escritor disciplina e consciência do seu público-alvo, o que influencia na seleção vocabular. Aqui, apresentam-se relatos de escritores renomados, reforçando a importância da disciplina para a escrita.

Por fim, a sétima fase, Verificação - Teste e resistência da sua nova ideia, corresponde ao que Marchioni (2018) denomina de degustação da escrita. É a hora em que o "juiz surge de forma expressiva. Nesta parte a orientação é espalhar cópias do texto produzido para pessoas, evitando-se os amigos frágeis, que correspondam ao público-alvo, que foi previamente definido.

Em suma, o livro consegue cumprir seu objetivo a partir da expertise do autor sobre as técnicas de escrita criativa, sem deixar que as estratégias expostas assumam status de verdades absolutas. Por sua apurada descrição conceitual, abordagem didática e abastado diálogo intertextual, identificam-se na obra conteúdos de elevado potencial 
para escritores veteranos e iniciantes, estudantes universitários e professores de diferentes áreas de conhecimento. Tal versatilidade revela-se promissora para a prática da escrita criativa em um viés de uma educação contextualizada e, como jornalista, Marchioni (2018) reconhece o papel da comunicação para as relações sociais, o que permite considerar, também, a produção comunicacional semiárida. E, como relata Di Nizo (2008), a escrita pode ser aprendida e ensinada. Essa é grande mensagem de Marchioni (2018), que convida você, leitor, a "mergulhar" no universo da produção escrita.

\section{Referências}

ALENCAR, Eunice Soriano de. Psicologia da criatividade. Porto Alegre: Artes Médicas, 1986.

BANDEIRA, Manuel. O itinerário de Pasárgada. Rio de Janeiro: Nova Fronteira, 1984.

DI NIZZO, Renata. Escrita criativa: o prazer da linguagem. São Paulo: Summus, 2008.

MARCHIONI, Rubens. Escrita criativa: da ideia ao texto. São Paulo: Contexto, 2018. 